\title{
Manufacturing Strategy in Gerabah Business
}

\author{
Anwar ${ }^{1}$ and A. Ratna Sari Dewi ${ }^{2}$ \\ ${ }^{1}$ State University of Makassar, Indonesia, e-mail: Anwar.rauf82@gmail.com \\ ${ }^{2}$ Hasanuddin University, Indonesia, e-mail: Ratna_fe@unhas.ac.id
}

\begin{abstract}
The purpose of this study is to build a sustained competitive advantage for the gerabah business through the development of a manufacturing strategy. The specific target of this study is to analyze the application of manufacturing strategies as a competitive weapon in the gerabah business. The design of this study is quantitative descriptive. The population of this research is gerabah business in Takalar Regency. The final sample is 149 businesses. The sample unit is a gerabah business located in Pattallassang District, Takalar Regency with a total of 149 businesses. Respondents are business owners. Data collection through surveys using questionnaires. Data analysis used in this study is descriptive statistics. The findings of the study indicate that the application of a fairly good manufacturing strategy in production activities is able to encourage the ability of the gerabah business to compete. Quality strategy priorities, shipping strategies, flexibility strategies, and cost strategies provide an important role in the implementation of manufacturing strategies. Priority quality strategies are considered the most important in the implementation of manufacturing strategies based on respondents' ratings.
\end{abstract}

Keywords: Manufacturing strategy

\section{Introduction}

Small business growth strongly supports economic progress in Indonesia. This sector in macro terms can create enormous employment opportunities in the last five years (2013-2017) which can absorb 97.65\% of the workforce and create added value to GDP of 56.53\% compared to large industries. In addition, the growth of the small business sector over the past five years (2013-2017) reached $10.89 \%$ while the Large Industry (IB) actually decreased by $7.38 \%$ (Ministry of Cooperatives and SMEs, 2017). This reality is in line with Kuncoro's (2000) opinion that Indonesian SMEs significantly promote new jobs, new businesses, and make a major contribution in reducing poverty. These figures reflect how Indonesia really depends on the growth of small businesses and will be a key factor for developing the Indonesian economy.

Various developments are quite important in the development of small businesses, but have not grown as expected. Various problems that generally inhibit industrial growth, as well as those specifically faced by certain industries, are internal problems regarding non-optimal manufacturing (starting from raw material supply, production capability, mastery of technology, to product competitiveness) and external issues regarding alignments and public awareness to use domestic products (Ministry of Industry, 2014). This condition has an impact on the low productivity produced and not a few small businesses experience business failures (Riyanti, 2003). This means that high performance of small businesses is an important necessity in survival, so attention is needed in understanding how to improve the performance of small businesses in the economic market (Pribadi and Kanai, 2010).

Leading small businesses in Takalar Regency experienced rapid growth over the last three years in the year (2015-2017) in terms of the number of businesses and labor absorption, but did not contribute significantly to the GRDP of Takalar District (BPS Takalar, 2017). This means that economic growth in Takalar District is still not optimal and still needs improvement. This condition also illustrates that small businesses have not been able to provide maximum added value to the achievement of regional economic 
activities or performance. One of the core industries of leading commodities in Takalar Regency is the gerabah business.

The main problem for the gerabah business is that the level of technology used is still limited so product creation is also still limited, the high market competition, market share by imported products also increasingly complicates the marketing of pottery. From the strength of the gerabah business, the availability of raw materials and sufficient labor is available (BPS, Takalar 2017).

Management of resource-based enterprises (RBV) encourages companies to create special competencies (Prahalad and Hamel, 1990; Grant, 2010) and provides strategic choices to achieve sustainable competitive advantage (Barney, 1991; Grant, 2010). The RBV's view directs company management to identify, master, and develop manufacturing strategies in order to produce optimal performance (Slack, 2002).

Manufacturing strategies are seen as effective manufacturing forces and are competitive weapons for achieving business and corporate goals (Swamidas and Newell, 1987). Competitive priorities or dimensions of competitiveness of manufacturing strategies in this study include the dimensions of cost, quality, delivery and flexibility (Hayes and Wheelwright, 1984; Chase, et al., 2004; Krajewski, et al., 2007, and Heizer and Render, 2008). The four dimensions of the competitiveness of the manufacturing strategy are not mutually excluded from each other, but are an integrated and mutually reinforcing entity. Amoako-Gympah and Boye (2001) explain that the choice of manufacturing strategies in small companies is different from large companies in response to the level of competition, where small companies are responded with an emphasis on cost and flexibility, while large companies with an emphasis on quality and flexibility. This is interesting to study more deeply about the industrial environment as a reflection of the conditions of small business competition in Indonesia as one of the developing countries. Some research on manufacturing strategies in SMEs (Chen, 1999; Sum, 2004; Oltra and Flor, 2010; Hung et al. 2011; and Rosli, 2012) have not investigated the relationship with their business environment.

\section{Research Methodology}

Methodologically, this type of research is quantitative descriptive. The research location is Pattallassang District in Takalar Regency. The reason is because the three districts are centers of gerabah business. The population of the gerabah business in Takalar District was only 153 businesses, so the entire population was used as research samples (saturated samples). The final sample was 149 businesses. The sample unit is a gerabah business located in Pattallassang District, Takalar Regency with a total of 149 businesses. Respondents are business owners. Data collection through surveys using questionnaires. Data analysis used in this study is descriptive statistics.

\section{Result and Discussion}

The manufacturing strategy is a gerabah business in managing production resources to produce and distribute products as the best support for competitive strategies. The manufacturing strategy in this study is reflected through four indicators, namely the strategy of cost, quality, flexibility and delivery. Descriptions of respondents' perceptions of manufacturing strategies are shown in tables. 
Table 1. Description of Respondents' Perception on Cost Strategy

\begin{tabular}{|c|c|c|c|c|c|c|c|c|c|c|c|c|c|}
\hline & \multirow{3}{*}{ Indicator/Item } & \multicolumn{10}{|c|}{ Answer Frequency (F) \& Percentage (\%) } & \multirow{3}{*}{ Mean } & \multirow{3}{*}{$\begin{array}{l}\text { Index } \\
(\%)\end{array}$} \\
\hline & & \multicolumn{2}{|c|}{$\begin{array}{l}\text { STS } \\
(1)\end{array}$} & \multicolumn{2}{|c|}{ TS (2) } & \multicolumn{2}{|c|}{ TS (3) } & \multicolumn{2}{|c|}{ S (4) } & \multicolumn{2}{|c|}{ SS (5) } & & \\
\hline & & $\mathrm{f}$ & $\%$ & $\mathrm{f}$ & $\%$ & $\mathrm{f}$ & $\%$ & $\mathrm{f}$ & $\%$ & $\mathrm{f}$ & $\%$ & & \\
\hline X11 & $\begin{array}{l}\text { Reduction of raw material } \\
\text { costs }\end{array}$ & 0 & 0 & 2 & 1 & 47 & 32 & 82 & 55 & 18 & 12 & 3,78 & 75,60 \\
\hline $\mathrm{X} 12$ & Reduction of labor costs & 0 & 0 & 27 & 18 & 77 & 52 & 29 & 19 & 16 & 11 & 3,05 & 64,60 \\
\hline $\mathrm{X} 13$ & Reduction of other costs & 0 & 0 & 0 & 0 & 30 & 20 & 71 & 48 & 48 & 32 & 4,12 & 82,40 \\
\hline X14 & $\begin{array}{l}\text { Increased production } \\
\text { capacity }\end{array}$ & 0 & 0 & 0 & 0 & 55 & 37 & 65 & 44 & 29 & 19 & 3,81 & 76,40 \\
\hline & & Stra & Egy & (X1 & & & & & & & & 3,69 & 74,75 \\
\hline
\end{tabular}

Source: processed data results, 2017

Table 2. Description of Respondents' Perception on Quality Strategy

\begin{tabular}{|c|c|c|c|c|c|c|c|c|c|c|c|c|c|}
\hline \multirow{3}{*}{\multicolumn{2}{|c|}{ Indicator/Item }} & \multicolumn{10}{|c|}{ Answer Frequency $(\mathrm{F})$ \& Percentage $(\%)$} & \multirow{3}{*}{ Mean } & \multirow{3}{*}{$\begin{array}{l}\text { Index } \\
(\%)\end{array}$} \\
\hline & & \multicolumn{2}{|c|}{$\begin{array}{l}\text { STS } \\
(1) \\
\end{array}$} & \multicolumn{2}{|c|}{ TS (2) } & \multicolumn{2}{|c|}{ TS (3) } & \multicolumn{2}{|c|}{$\mathrm{S}(4)$} & \multicolumn{2}{|c|}{$\mathrm{SS}(5)$} & & \\
\hline & & $\mathrm{f}$ & $\%$ & $\mathrm{f}$ & $\%$ & $\mathrm{f}$ & $\%$ & $\mathrm{f}$ & $\%$ & $\mathrm{f}$ & $\%$ & & \\
\hline $\mathrm{X} 21$ & Repair of product durability & 0 & 0 & 0 & 0 & 29 & 20 & 90 & 60 & 30 & 20 & 4,01 & 80,00 \\
\hline $\mathrm{X} 22$ & $\begin{array}{l}\text { Consistency of product } \\
\text { quality }\end{array}$ & 0 & 0 & 0 & 0 & 15 & 10 & 86 & 58 & 48 & 32 & 4,22 & 84,40 \\
\hline $\mathrm{X} 23$ & Work safety attention & 0 & 0 & 0 & 0 & 52 & 35 & 74 & 50 & 23 & 15 & 3,74 & 76,00 \\
\hline $\mathrm{X} 24$ & $\begin{array}{l}\text { Reduction of environmental } \\
\text { damage }\end{array}$ & 0 & 0 & 6 & 4 & 57 & 38 & 63 & 42 & 23 & 16 & 3,62 & 74,00 \\
\hline \multicolumn{12}{|c|}{ Quality Strategy (X2) } & 3,90 & 78,60 \\
\hline
\end{tabular}

Source: processed data results, 2017

Table 3. Description of Respondents' Perception on Flexibility Strategy

\begin{tabular}{|c|c|c|c|c|c|c|c|c|c|c|c|c|c|}
\hline & \multirow{3}{*}{ Indicator/Item } & \multicolumn{10}{|c|}{ Answer Frequency $(\mathrm{F})$ \& Percentage $(\%)$} & \multirow{3}{*}{ Mean } & \multirow{3}{*}{$\begin{array}{l}\text { Index } \\
(\%)\end{array}$} \\
\hline & & \multicolumn{2}{|c|}{$\begin{array}{c}\text { STS } \\
(1) \\
\end{array}$} & \multicolumn{2}{|c|}{$\mathrm{TS}(2)$} & \multicolumn{2}{|c|}{ TS (3) } & \multicolumn{2}{|c|}{$\mathrm{S}(4)$} & \multicolumn{2}{|c|}{ SS (5) } & & \\
\hline & & $\mathrm{f}$ & $\%$ & $\mathrm{f}$ & $\%$ & $\mathrm{f}$ & $\%$ & $\mathrm{f}$ & $\%$ & $\mathrm{f}$ & $\%$ & & \\
\hline $\mathrm{X} 31$ & $\begin{array}{l}\text { Adjustment of production } \\
\text { volume }\end{array}$ & 0 & 0 & 3 & 2 & 56 & 37 & 68 & 46 & 22 & 15 & 3,69 & 74,80 \\
\hline $\mathrm{X} 32$ & $\begin{array}{l}\text { Adaptation of customer } \\
\text { needs }\end{array}$ & 0 & 0 & 0 & 0 & 31 & 21 & 81 & 54 & 37 & 25 & 4,04 & 80,80 \\
\hline X33 & $\begin{array}{l}\text { Production order } \\
\text { arrangement }\end{array}$ & 1 & 1 & 1 & 1 & 48 & 32 & 61 & 41 & 38 & 25 & 3,38 & 77,60 \\
\hline & Flex & & & $6 y($ & & & & & & & & 3,70 & 77,73 \\
\hline
\end{tabular}

Source: processed data results, 2017 
Table 4. Description of Respondents' Perception on Delivery Strategy

\begin{tabular}{|c|c|c|c|c|c|c|c|c|c|c|c|c|c|}
\hline \multirow{3}{*}{\multicolumn{2}{|c|}{ Indicator/Item }} & \multicolumn{10}{|c|}{ Answer Frequency $(\mathrm{F})$ \& Percentage $(\%)$} & \multirow{3}{*}{ Mean } & \multirow{3}{*}{$\begin{array}{l}\text { Index } \\
(\%)\end{array}$} \\
\hline & & \multicolumn{2}{|c|}{$\begin{array}{c}\text { STS } \\
(1) \\
\end{array}$} & \multicolumn{2}{|c|}{$\mathrm{TS}(2)$} & \multicolumn{2}{|c|}{ TS (3) } & \multicolumn{2}{|c|}{$\mathrm{S}(4)$} & \multicolumn{2}{|c|}{ SS (5) } & & \\
\hline & & $\mathrm{f}$ & $\%$ & $\mathrm{f}$ & $\%$ & $\mathrm{f}$ & $\%$ & $\mathrm{f}$ & $\%$ & $\mathrm{f}$ & $\%$ & & \\
\hline $\mathrm{X} 41$ & Timeliness of production & 0 & 0 & 2 & 1 & 35 & 24 & 81 & 54 & 31 & 21 & 3,95 & 79,00 \\
\hline $\mathrm{X} 42$ & Delivery speed & 0 & 0 & 3 & 2 & 37 & 25 & 79 & 53 & 30 & 20 & 3,89 & 78,20 \\
\hline \multicolumn{12}{|c|}{ Delivery Strategy (X4) } & 3,92 & 78,60 \\
\hline
\end{tabular}

Source: processed data results, 2017

Table 5. Index of Manufacturing Strategy

\begin{tabular}{|lc|}
\hline \multicolumn{1}{|c|}{ Indicator/Item } & $\begin{array}{c}\text { Index } \\
(\%)\end{array}$ \\
\hline Manufacturing Strategy $(X)$ & 77,42 \\
\hline Interpretation of Index Value: $10-40 \%=$ Low $; 41-70 \%=$ Medium; $71-100 \%=$ High & \\
\hline
\end{tabular}

Source: processed data results, 2017

Description of respondents' responses / perceptions of manufacturing strategies in table 1 can be explained as follows:

1. The cost strategy is the way the owner regulates production costs to a minimum or the minimum wasted resources. Indicators are measured through 4 items, namely: reduction in raw material costs, reduction in labor costs, reduction of other costs in production, and increase in production capacity. Other cost reduction items received the highest response with a mean of 4.12. The item increase in production capacity received a response with an average of 3.83 and the item reduction in raw material costs received a response with an average of 3.78 and items for reducing labor costs received a response with an average of 3.23. Overall the implementation of the cost strategy obtained responses of respondents with a mean of 3.74. The results of this response indicate that the adoption of cost strategies is quite good with the main emphasis on reducing other costs in addition to emphasizing increasing production capacity, reducing raw material costs and reducing labor costs. Reduction of other costs in the production of gerabah business occurs at depreciation, repairs, and factory fixed assets and helper costs. Reducing costs by increasing production capacity occurs due to funding support in the supply of raw materials on a larger scale which directly affects the reduction of raw material costs. While the reduction in labor costs can occur from the wage system provided based on the number of production units produced or the bulk system.

2. Quality strategy is the way owners make products that are in accordance with specifications or meet consumer needs. Indicators are measured by 4 items, namely: improvement in product durability, consistency of product quality, work safety attention, and reduction of environmental damage. The product quality consistency item obtained the highest response with an average of 4.22 compared to items that improved product durability (4.01), work safety attention (3.81), and reduced environmental damage (3.69). Overall the implementation of the quality strategy obtained responses from respondents with an average of 3.93. The results of this response indicate that the implementation of a quality strategy in the earthenware business is good with the main emphasis on consistency in maintaining product quality while continuing to improve product durability, improve work conditions and safety, and reduce environmental damage. The earthenware business always prioritizes product quality that is consistent because it maintains customer trust from generation to generation. Small mistakes in production will be very easily known by customers who generally are 
able to distinguish the quality of the gerabah business. The durability of the gerabah business is also a major concern because one of the main benchmarks of the quality of the gerabah business can be seen from its durability. Attention to work safety is also a consideration in quality strategies to ensure business continuity by reducing the risk of accidents in the production process. Then reducing environmental damage is a consideration of the quality strategy to build a business image in the preservation of environmental functions without environmental pollution.

3. The flexibility strategy is the owner's way of responding to the rapid changes of processes, products and volume of consumer needs. Indicators are measured by 3 statement items, namely: adjustment of production volume, adaptation of customer needs, and arrangement of production sequences. Adaptation of customer needs gets the highest response with an average of 4.04 compared to the response to the order of production with an average of 3.90 and adjustment of production volume with an average of 3.73. Overall responses of respondents to the application of flexibility strategies with an average of 3.89. These results indicate that the adoption of flexibility strategies can be of good value with the main emphasis on rapid adaptation to customer needs in addition to emphasizing the proper arrangement of production sequences and rapid production volume adjustments to customer needs. Adaptation to customer needs quickly carried out gerabah business to consider consumer tastes that are more sensitive to the shape and color of gerabah business. Then setting the production sequence appropriately is done by the gerabah business to consider the efficiency and effectiveness of work. The making of pottery in Takalar Regency is generally carried out in two ways, namely traditional and semi-modern methods.

4. The shipping strategy is the way the owner meets the delivery schedule or speed in response to consumer demand. Indicators are measured by 2 statement items, namely: production timeliness and speed of delivery. Timeliness of production received a higher response with an average of 3.95 compared to the speed of delivery with an average of 3.91. Overall responses of respondents to the implementation of the delivery strategy with an average of 3.93. These results indicate that the implementation of the delivery strategy is considered good with the main emphasis on the timeliness of production in addition to the emphasis on the speed of product delivery. The production time in the gerabah business for traditional wet production is generally carried out in the morning and finished during the day, while for wet production fermentation is generally carried out in the morning and finished the next day. Product delivery can be done quickly because of the support of existing transportation facilities.

Overall, the results of the analysis show that the application of manufacturing strategies in production activities is quite good based on the average perception index value obtained at 77.42 percent. Specifically, the application of manufacturing strategies places more emphasis on quality strategies and delivery strategies than flexibility strategies and cost strategies. The results of this analysis confirm that gerabah businesses use quality strategies and delivery strategies as the main competitive weapons compared to flexibility strategies and cost strategies to support competitive strategies.

The results of the analysis show that the application of manufacturing strategies in production activities is quite good. Specifically, the application of manufacturing strategies places more emphasis on quality strategies and delivery strategies than flexibility strategies and cost strategies. The results of this analysis confirm that gerabah businesses use quality strategies and delivery strategies as the main competitive weapons compared to flexibility strategies and cost strategies to support competitive strategies.

The results of this study are in line with the RBV theory which emphasizes the importance of management of the company's resources and capabilities as a source of competitive advantage (Barney, 1995; Aaker, 2001; Hitt et al., 2011) that establish manufacturing strategies (Hill and Jones, 2007). The findings of this study also reinforce the concept proposed by Schroeder $(1989,2011)$ and Ward et al., (1996) that the internal environment can influence manufacturing strategies through the availability of 
resources. In addition, this finding also corroborates the opinion of Chase et al. (2004) that manufacturing strategies must be linked to the company's resources and capabilities.

The findings of this study illustrate that the earthenware business in Takalar District has not made optimal efforts to control and control the resources used as core competencies for the basis of implementing manufacturing strategies in production activities. Resources in the gerabah business have not been able to be managed optimally with the capabilities they have, thus reducing their potential to produce competitive advantage. Among the management of existing resources, only reputation resources are more optimally achieved while physical resources, organizational resources, financial resources, human resources, and technological resources have not achieved optimal management. The ability to exploit low resources in the earthenware business is evidence that the strategic resources of the gerabah business are still weak in providing support for the implementation of manufacturing strategies.

\section{Conclusion}

The implementation of a fairly good manufacturing strategy in production activities is able to drive the ability of the gerabah business to compete. Priority of quality strategies, delivery strategies, flexibility strategies, and cost strategies provide an important role in implementing manufacturing strategies. The priority of the quality strategy is considered to be the most important in implementing a good manufacturing strategy based on the respondent's judgment. These results indicate that the priority of the quality strategy is considered to be appropriate as the basis for implementing manufacturing strategies to contribute to increasing the value of competitiveness in the gerabah business.

\section{References}

Barney, J B. (2002). Gaining and sustaining competitive advantage. United States of Amerika, NJ: Prentice Hall.

Bridoux, F. 2004. A Resource-Based Approach to Performance and Competition: An Overview of the Connections between Resources and Competition, Belgium, Institut et de Gestion, Universite Catholique de Louvain.

Chase, Richard B., Nicholas J. Aquilano, and F. Robert Jacobs. 2004. Operation Management for Competitive Advantage. New York:McGraw-Hill Companies, Inc.

Chio, Y.C. (2011) Internationalization, intangible asset, \& Taiwan SME's performance: Evidence of an Asian NIE's (Newly-Industrialized Economy). African Journal of Business Management, 5 (3), 641-655

Choo, C.W., \& Bontis, N. (2002). The strategic management of intellectual capital and organizational knowledge. New York: Oxford University Press.

Collis, David dan Montgomery, Chinthia, 2004. Corporate Strategy: A Resource-Based Approach, $2^{\text {ad }}$ Edition, Irwin McGraw-Hill, Boston

Daum, J.H. (2005). Intangible asset-based enterprise management-a practical approach. This paper has been presented at the 2005 PMA IC Symposium, Stern School of Business, New York University, NYC/USA. (On-Line) Available at http://www.juergendaum.com/news/0115_2006.htm

David, Fred R. 2009. Manajemen Strategis: Konsep. Edisi 12 Buku 1. Jakarta: Salemba Empat.

Dinas Perindustrian dan Perdagangan (Disperindag) Sulbar. 2014. Daftar Sentra Industri Kecil dan Menengah. Disperindag Sulbar.

Edelman, Linda F., Candida G. Brush., dan Tatiana Manolova. (2002). The mediating role of strategy on small firm performance. Journal of Business Venturing. Working Paper \#2004-03.

Eisenhardt, K. M., dan Santos, F. M. (2000). Resource based view: A new theory of strategy. Stanford University 
Grant, Robert M. 2010. Contemporary Strategy Analysis, $7^{\text {th }}$ Edition, John Wiley dan Sons, Ltd. Hayes, Robert H., and Pisano, Gary P. 1996. Manufacturing Strategy: At The Intersection Of Two Paradigm Shifts. Production and Operations Management. 5 (1), pp. 25-41

Hayes, R.H., Wheelwright, S.C. 1984. Restoring Our Competitive Edge: Competing Through Manufacturing, Wiley: New York.

Hayes, Robert H. 1985. Strategic Planning - Forward in Reverse?. Harvard Business Review, NovemberDesember, 111-119.

Heizer, Jay dan Render, Barry. 2009. Manajemen Operasi. Edisi 9 Buku 1. Jakarta: Salemba Empat.

Hill, Charles W.L dan Jones, Gareth L. 1998. Strategic Management: An integrated Approach, Houghton Mifflin Company. New York

Hitt., Michael A., Ireland., R.D., dan Hoskisson., R.E., 2011. Strategic Management: Competitiveness and Globalization: Concepts. Ninth Edition. USA: South-Western Cengage Learning.

Hunger, J.David., dan Wheelen., Thomas L., 2003, Manajemen Strategis, Penerbit Andi, Yogjakarta.

Hung, Shu-Chi., Hung, Shiu-Wan, dan Lin, Ming-Ji James. (2011). How different strategic alliances affect manufacturing competitive priority and firm performance: an empirical study of SMEs. Sbaer.uca.edu/research/icsb/2011/168.pdf 